\title{
THE NEWLY DISCOVERED NEOGENE MAAR VOLCANO NEAR THE MARIÁNSKÉ LÁZNĚ, WESTERN BOHEMIA
}

\author{
Jan VALENTA ${ }^{1) *}$, Vladislav RAPPRICH ${ }^{2)}$, Zuzana SKÁCELOVÁ ${ }^{2)}$, \\ Renata GAŽDOVÁ ${ }^{1)}$ and Lucia FOJTÍKOVÁ ${ }^{1)}$ \\ ${ }^{1)}$ Institute of Rock Structure and Mechanics, Academy of Sciences of the Czech Republic, V Holešovičkách 41, \\ 18209 Prague, Czech Republic \\ ${ }^{2)}$ Czech Geological Survey, Klárov 3, 11821 Prague, Czech Republic \\ *Corresponding author's e-mail: valenta@irsm.cas.cz
}

\section{ARTICLE INFO}

Article history:

Received 2 May 2013

Accepted 18 October 2013

Available online 28 November 2013

Keywords:

Maar

Diatreme

Gravity survey

Magnetic survey

Neogene volcanism

\section{ABSTRACT}

The local magnetic maxima near the village Rájov (NE of Mariánské Lázně) revealed by airborne magnetometry was further surveyed using ground gravimetry and magnetometry. The measured magnetic data revealed a positive magnetic anomaly in the centre of the surveyed area. The measured gravity data showed two small-scale gravity minima. The geophysical data are interpreted by a presence of the maar-diatreme volcano, basic intrusions, and a lava flow filling the maar crater. The overall interpretation suggests, that volcanism in this area probably started with the phreatomagmatic eruption of the Rájov maar and then continued with the Strombolian eruption of the nearby Podhorní vrch volcano.

\section{INTRODUCTION}

The Cenozoic volcanic activity in the Bohemian Massif (Central Europe) took place during several periods in Paleogene, Neogene, and also Quaternary. It is distributed over the northern and western part of the Bohemian Massif (Czech Republic, SE Germany, SW Poland) with the highest spatial density within the Eger Rift and smaller amounts of volcanic bodies on the rift shoulder reducing the abundance with increasing distance from the rift (e.g., Ulrych et al., 2011). Diverse magma sources and complex petrogenetic and differentiation processes lead into a wide spectrum of chemical composition of erupted magmas. Variable chemical composition as well as various settings of eruptions lead to many different styles of manifestations of volcanic activity creating many different volcanic land-forms. Despite more than a hundred years of intensive geological studies new researches still alter the view. New data on setting of volcanoes and volcanic complexes in the Bohemian Massif can be provided also by geophysical surveys (e.g., Skácelová et al., 2009; Skácelová et al., 2010; Valenta et al., 2011).

In 1965 the airborne magnetometry was carried out in the western Czech Republic. The measured magnetic field revealed a magnetic anomaly near the village Rájov (Fig. 1), only $5 \mathrm{~km}$ NE of the Mariánské Lázně. However, this anomaly has remained further unexplored until 2008 when Šalanský (2009) realized a ground magnetometric profile across it. He interprets the measured magnetic maxima by presence of a Cenozoic maar volcano and basaltic dykes (Šalanský, 2009).

Maar-diatreme volcanoes represent one of the volcanic forms in the Bohemian Massif. The origin of maar-diatreme volcanoes results from explosive interaction between magma and subsurface water. The explosion is caused by shock vaporization of water due to contact with a hot magma. The resulting diatreme is a funnel-shaped crater filled in deep by breccia of original country rock "fluffed up" with the explosion. The upper parts are later on filled with post-eruptive sediments (cf. Lorenz et al., 2003; Lorenz and Kurzslaukis, 2007).

This brief outline of a diatreme formation clearly shows which path the eventual geophysical prospection should take. First of all, the gravity low should be observed when crossing the diatremes - the country rock disintegrated with the explosion has lower densities than the coherent and massive country rock. Moreover, the post-eruptive sediments usually also exhibit lower densities compared with their surroundings. Next, the magmatic dykes feeding the system and penetrating the diatreme have usually increased magnetization compared with the country rocks. Gravity and magnetics anomalies are often combined and interpreted together (Cassidy et al., 2007; Loera et al., 2008; Mrlina et al., 2009; Blaikie et al., 2012). Finally, also the seismic and geoelectrical methods can image the diatreme and magma intrusion based on differences in elastic and electrical properties of country rock and diatreme filling (Emilia 


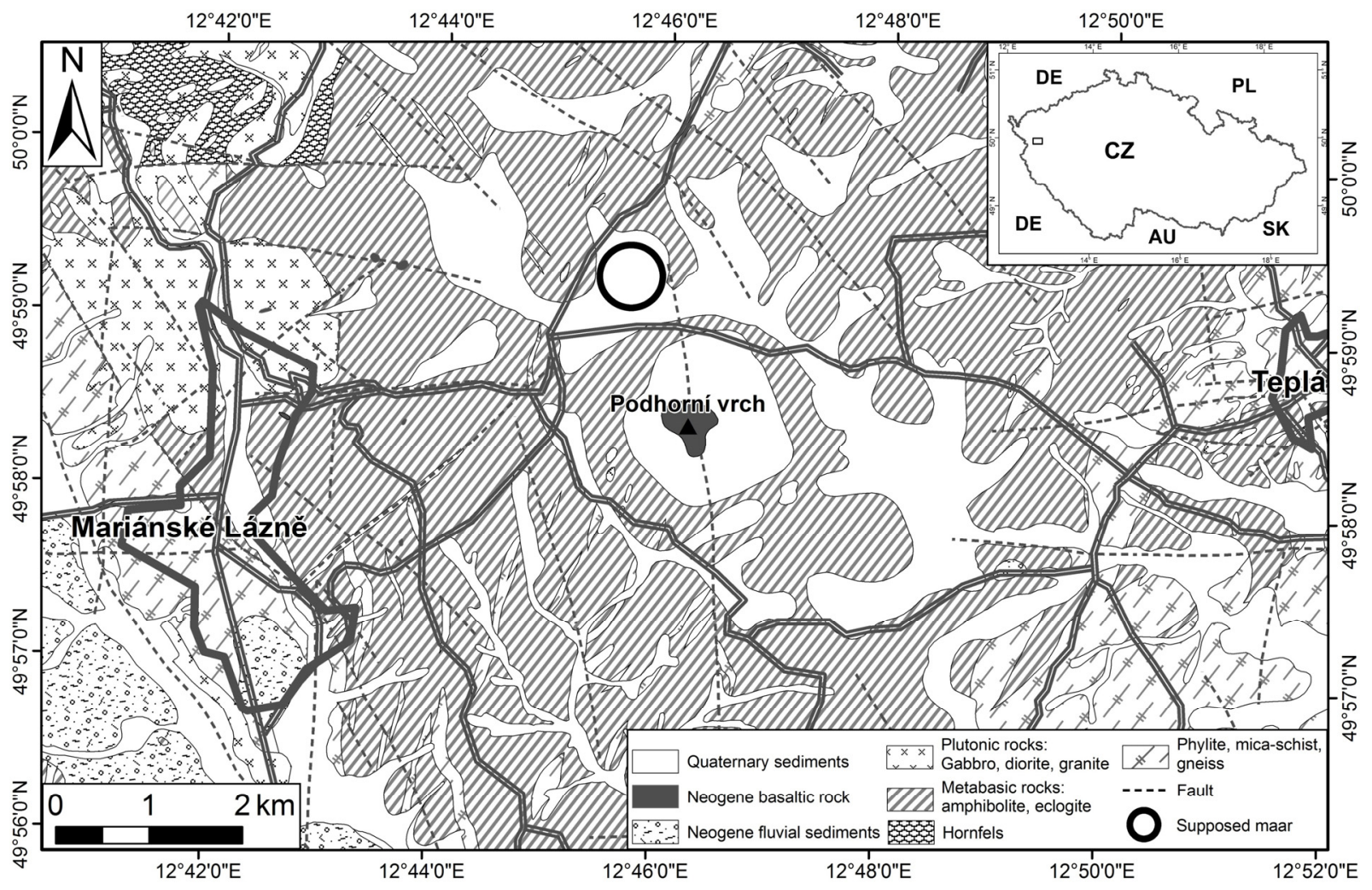

Fig. 1 Geological setting of the investigated area (see inset map for location within the Czech Republic). Geological map simplified after Tonika (1999).

et al., 1977; Brunner et al., 1999; Skácelová et al., 2010; Gebhardt et al., 2011; Bolós et al., 2012). However, the last two methods are not used as frequently as gravimetry and magnetometry, mainly due to their limited depth reach (in their most common and affordable configuration for the nearsurface geophysics). On the other hand they offer higher spatial resolution and less ambiguity in interpretation compared to potential methods.

Based on above mentioned knowledge and assumptions, we decided to investigate the Rájov magnetic anomaly (see Fig. 1 for location) further. We wanted to extend the one magnetic profile of Šalanský to get a $2 \mathrm{~d}$ distribution of magnetic anomalies and, more importantly, to measure also several gravimetrical profiles (Fig. 2) to add another geophysical method for more reliable interpretation. What is more, the gravity measurements would also enable construction of numerical model to support the interpretation.

\section{GEOLOGICAL SETTINGS}

The studied locality is located in the Slavkovský les Highland - a wedge between two grabens: Eger Rift to the north and Cheb-Domažlice graben to the west (e.g., Ulrych et al., 2003, 2011). Volcanic conduits in studied area penetrate complex of predominantly metabasic rocks of the Mariánské Lázně Complex (MLC: amphibolites, metagabbros, eclogites, serpentinites, actinolite schists - Štědrá et al. 2002) adjacent to high grade gneisses of the Teplá Highland complex to east (Žáček et al., 1993) and Variscan Bor Pluton with granites and diorites to the west (Klomínský et al., 2010). The plutonic rocks are mantled by lower-grade meta-volcanosedimentary Kladská Unit (Kachlík, 1994).

According to the geological map (Fig. 1) the Rájov maar penetrates amphibolites with smaller bodies of eclogites. The densities of amphibolites are reported to be $2960 \pm 80 \mathrm{~kg} / \mathrm{m}^{3}$ and densities of eclogites varies about $3370 \mathrm{~kg} / \mathrm{m}^{3}$ (Jacoby and Smilde, 2010). The magnetic susceptibility of amphibolites measured on outcrops in the vicinity of the study area ranges between 300 and $550 \times 10^{-6} \mathrm{SI}$ and that of eclogites is about $600 \times 10^{-6} \mathrm{SI}$.

There is no volcanic rock cropping out in the depression supposed to represent the Rájov maar, but about $1 \mathrm{~km}$ south of the maar, the Podhorní vrch Hill rises up. The Podhorní vrch Hill is an erosional remnant of a monogenetic volcano. The erosion has exposed a feeder of olivine nephelinite with remnants of pyroclastic rocks (Cajz, 1992). We interpret the poorly sorted, clast-supported scoria deposits (Fig. 3) with slightly observable periclinal stratification as a remnant of superficial facies of a scoria cone produced by a Strombolian eruption (e.g., Head and Wilson, 1989; Rapprich et al., 2007; Tietz et al., 2011; Büchner and Tietz, 2012). According to the K-Ar data, (Ulrych et al., 2003), the Podhorní vrch Hill is of the Mid Miocene age (12.4 Ma). The 


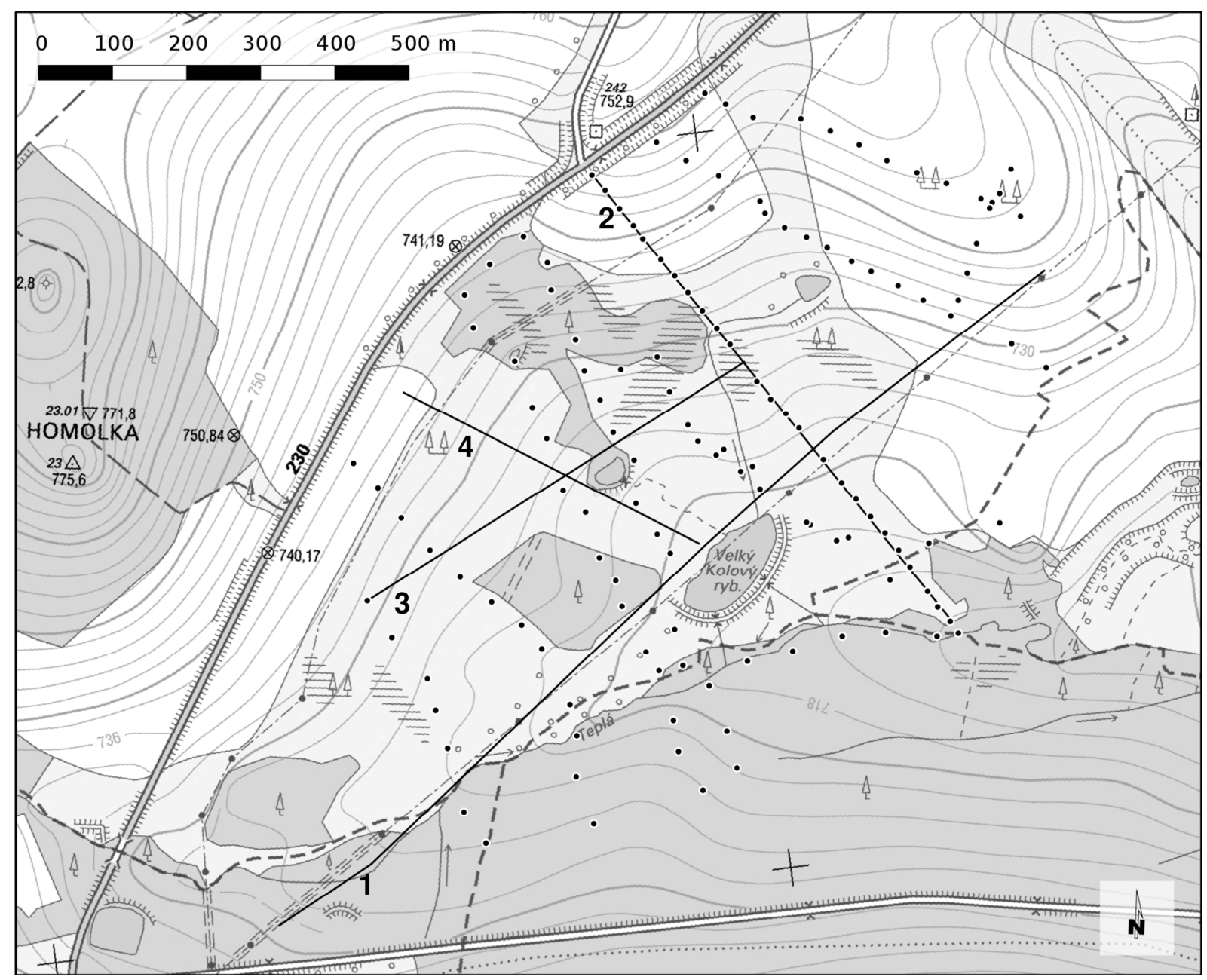

Fig. 2 Gravimetrical profiles (lines 1 to 4 and points of ground magnetometric survey).

volcanic rocks from the Podhorní vrch Hill have the magnetic susceptibility in the range of 20000 to $24000 \times 10^{-6}$ SI. The density of the olivine nephelinite is very high - about $3100 \mathrm{~kg} / \mathrm{m}^{3}$ (Ibrmajer and Suk, 1989)

The sedimentary cover in the area of Rájov is mostly of Quaternary age and is of fluvial and colluvial origin with many localities hosting peat. Neogene sediments are documented in the valley. The densities of sediments varies depending on material composition, compaction and water saturation. The compaction of the near-surface sediments is very low and hence densities are also low, usually ranging between $1500 \mathrm{~kg} / \mathrm{m}^{3}$ for soils and $2200 \mathrm{~kg} / \mathrm{m}^{3}$ for wet clays (Jacoby and Smilde, 2010). The density of peat could be extremely low, even as low as $1050 \mathrm{~kg} / \mathrm{m}^{3}$ (Jacoby and Smilde, 2010).

\section{DATA ACQUISITION AND PROCESSING 3.1. GRAVITY SURVEY}

The gravity data were measured along four perpendicular profiles crossing the area of the supposed maar-diatreme volcano. The lengths of the profiles were $1360 \mathrm{~m}$ (profile 1), $780 \mathrm{~m}$ (profile 2),
$600 \mathrm{~m}$ (profile 3) and $450 \mathrm{~m}$ (profile 4). The station spacing on the profiles 1 and 2 was 30 metres and 50 metres on the profiles 3 and 4 . The gravity was measured using the Scintrex CG-5 relative gravity meter. The base station was situated roughly in the centre of the area on the solid ground and was reoccupied every 2-3 hours to correct the measured data for an instrument drift.

The individual gravity readings averaged gravity samples taken during the 60 second intervals and two or three individual gravity readings were usually measured on individual stations. These individual readings were then averaged to make a gravity datum for a station. In case of unfavourable measuring conditions (swampy areas), the number of individual gravity readings was higher and before averaging the outliers were removed.

The topographical survey was carried out using the Leica TC1010 total station. Based on the repeated measurements, the average accuracy in heights was $0.166 \mathrm{~m}$. Thus the estimated uncertainty in gravity data introduced by uncertainties in heights (difference in Bouguer anomalies for a density $2900 \mathrm{~kg} / \mathrm{m}^{3}$ and the average errors in heights) is $\pm 0.031 \mathrm{mGal}$. 


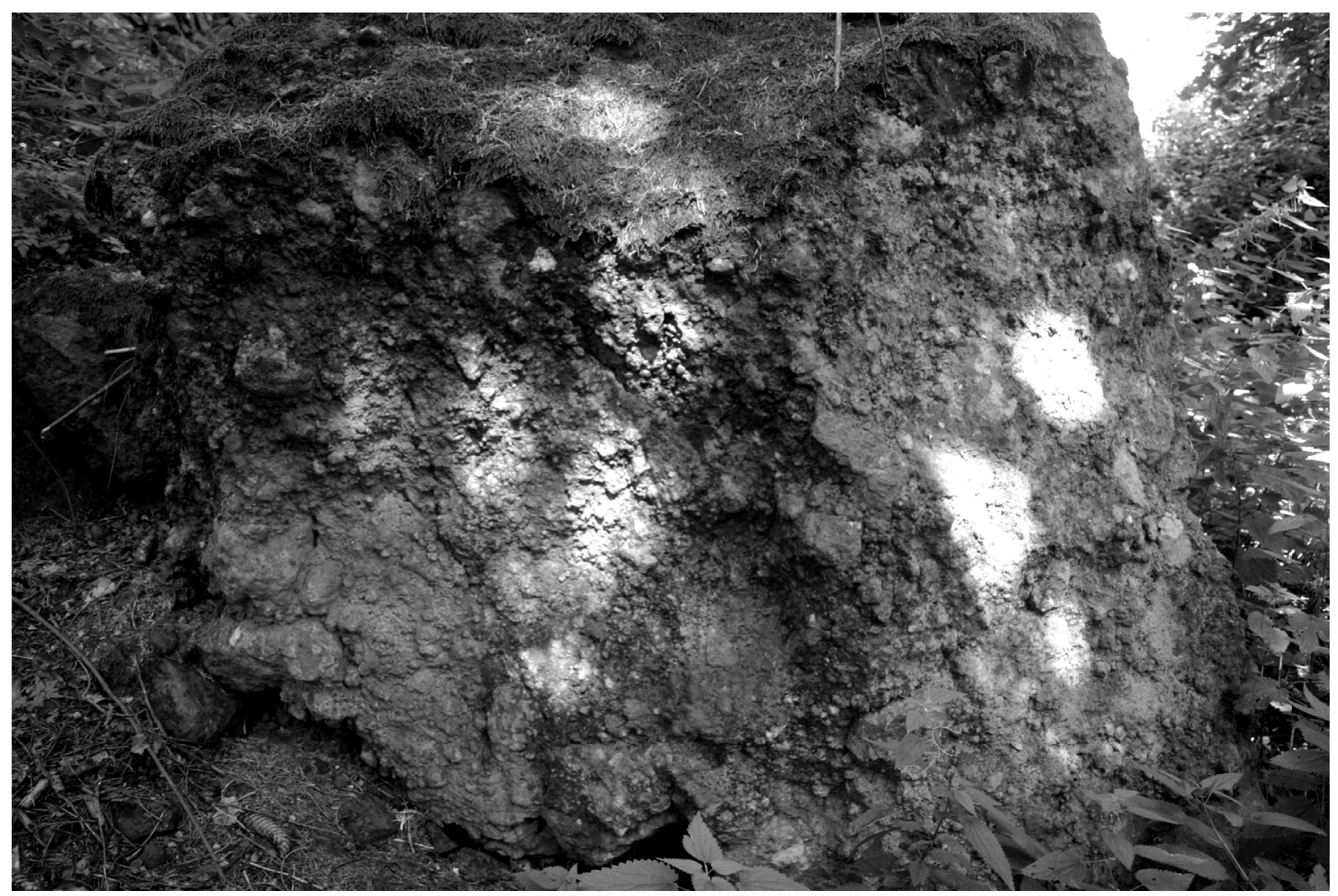

Fig. 3 Scoriaceous deposits at the top of the Podhorní vrch Hill (about $1 \mathrm{~km}$ south of Rájov maar).

The measured data were, first of all, corrected for the instrument drift based on repeated measurements on the base station. The tidal corrections are applied automatically by the gravity meter and their small residuum is then removed within the instrument drift corrections. From the total number of 97 gravity points 5 points (excluding the base station) were measured twice to determine the precision of measurement. The average error of gravity readings based on repeated measurements was $0.003 \mathrm{mGal}$. The next step was calculation of free-air and Bouguer anomalies and terrain corrections. The density used for the Bouguer slab was $2900 \mathrm{~kg} / \mathrm{m}^{3}$, which is an approximate estimated density of the country rock (amphibolites). The terrain corrections were computed on the altimetry grid of the Czech Land Office with a spatial resolution of $5 \mathrm{~m}$. The grid was further recomputed to the spatial resolution of $1 \mathrm{~m}$ within the area of survey and its near vicinity. The gravity effect of the terrain is then computed as rectangular prisms on a square grid. The average amplitude of terrain corrections was $0.259 \mathrm{mGal}$. The error of terrain corrections were not computed since the errors of the DEM are not known. Hence, the overall error of the gravity anomaly is $\pm 0.034 \mathrm{mGal}$ (excluding the error of terrain corrections). The map of Bouguer anomalies (Fig. 4) shows that the gravity data are generally increasing from $\mathrm{NW}$ to SE. Therefore, the next step was removing the regional field approximated by a plane. Resulting residual gravity field (Fig. 5) clearly shows two gravity lows on the first profile. However, they are very narrow which does not fit the interpretation of Salanský (2009), who proposed a wide diatreme (approximately 600 metres in diameter). Also the difference between its minimum and maximum values is only $1.6 \mathrm{mGal}$ (Fig. 5), which is less than was expected in case of such a large diatreme.

\subsection{MAGNETIC SURVEY}

The ground magnetic survey was carried out using the portable proton magnetometer PGM-1 (SatisGeo, Ltd.). The measurement points covered the whole area of the supposed maar-diatreme volcano (Fig. 2). In total 135 magnetic points were measured with accuracy of $\pm 1 \mathrm{nT}$. One of the profiles followed the course of the gravity profile 2 and the measurement points were identical for both methods. The gravity profile 1 could not be used for magnetic measurements due to power lines running nearby. The magnetic data was corrected for daily variations (about $10 \mathrm{nT}$ ) by repeated measurements on the base station. The amplitudes of variations were, however, much lower compared to amplitudes of the registered magnetic anomaly.

The measured magnetic field (Fig. 6) shows a narrow positive magnetic anomaly in the centre of the area. The anomaly is elongated on the SW-NE 


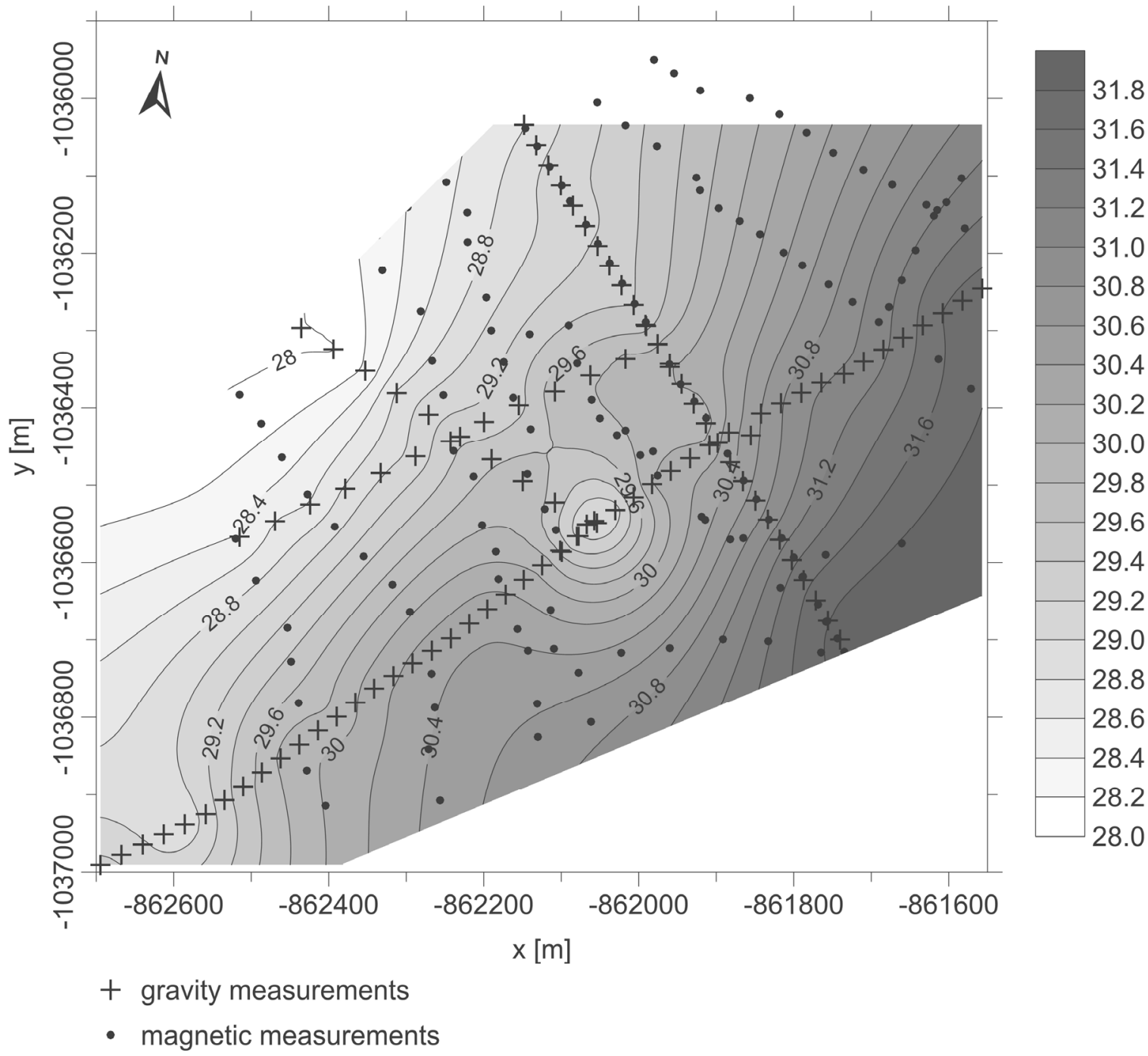

Fig. 4 Bouguer anomalies. Reduction density used for the Bouguer slab was $2900 \mathrm{~kg} / \mathrm{m}^{3}$.

direction and coincides with increased values of the gravity field on the north and west side of the gravity low (Figs. 4 and 5). On its SW part the narrow anomaly broadens and continues beyond the study area.

\section{RESULTS}

The residual gravity field (Fig. 5) clearly shows two gravity lows on the first profile. They are very narrow which does not fit the interpretation of Šalanský (2009), who proposed wide diatreme (approximately 600 metres in diameter). Also the difference between minimal and maximal gravity values is low - only $1.6 \mathrm{mGal}$. However, the gravity high separating these two minima correlates with the highest values of the magnetic field within the area (Fig. 6). This magnetic anomaly forms a band in a NS direction and turning eastwards on its north end. The south end of this anomaly points in the direction of the Miocene Podhorní vrch Volcano (Fig. 1). Hence, we could assume a dense coherent mafic magnetic body to be present here.

We have carried out the interpretation using the forward modelling and a trial and error technique. For the forward modelling we have used the Grav2dc code by Gordon Cooper (Cooper 1997, Cooper 2012). This program calculates gravity effects of $2.5 \mathrm{~d}$ bodies using the Talwani algorithm. Finally we have set up a model that fits well the observed gravity data and is also coherent with geological assumptions (Fig. 7). In contrast to the residual gravity field plotted in Figure 5 we have used different approximation of the regional field for the forward modelling. In the former case, we have approximated the regional field by a plane which we have fitted through the whole dataset. Involving also the anomalous values in the computation of a regional field could seriously bias the result and hence it is usable only for a general overview map like in the case of Figure 5. 


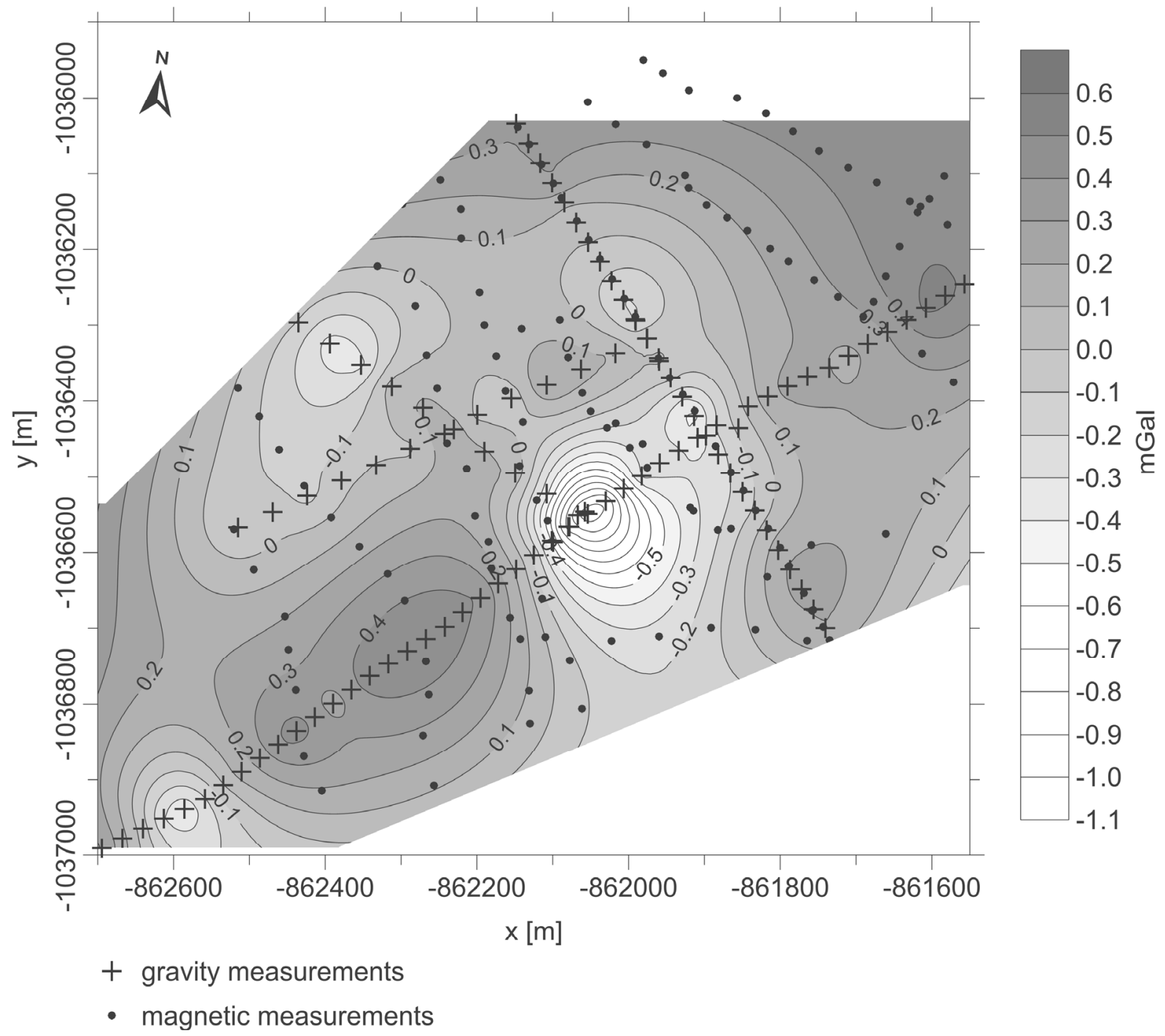

Fig. 5 Residual gravity anomalies. The regional field was approximated by a plane. The gravity low in the middle of the measured area is supposed to be caused by a low density material filling the diatreme.

For the forward modelling, however, usually more rigorous approach is used where the regional field is fitted only through data not affected by gravity anomalies. In this case this, unfortunately, could not be done for the whole dataset due to low number of gravity points outside of the anomaly. Therefore, only the modelled profile was treated this way.

The modelled maar-diatreme volcano is almost $1000 \mathrm{~m}$ in diameter and the depth is also about a kilometre. Three bodies of coherent volcanic rock are located within the maar-diatreme structure. The largest, funnel-shaped body is situated in the lowest part of the diatreme. Another one is a vertical tabular body penetrating diatreme and country rocks. The last one is a horizontal nearly tabular to lens-shaped body in the upper part of the structure. According to the model, the top of the volcanic crater is covered with Neogene to Quaternary sediments and peat layers which is in accordance with geological map (Fig. 1).
The densities used for modelling were as follows: $2900 \mathrm{~kg} / \mathrm{m}^{3}$ for the country rock amphibolites (and the same density for the Bouguer slab), $2700 \mathrm{~kg} / \mathrm{m}^{3}$ for the bottom part of the diatreme and $2650 \mathrm{~kg} / \mathrm{m}^{3}$ for the upper, $3100 \mathrm{~kg} / \mathrm{m}^{3}$ for the basic coherent volcanic rock (olivine nephelinite) - basic dyke, intrusion and lava in Figure $7,2000 \mathrm{~kg} / \mathrm{m}^{3}$ for the Neogene and Quaternary sediments and $1500 \mathrm{~kg} / \mathrm{m}^{3}$ for the peat.

\section{DISCUSSION}

The low differences in gravity within the crater and off the crater suggest, that the maar-diatreme structure is in significant part filled with a dense material - a coherent volcanic rock. The biggest modelled coherent body in the lower part of the structure could be interpreted in terms of a large intrusion, most likely injected into the brecciated root zone of the maar explosion. The second one seems to be a basic dyke cutting the country rocks NE of the 


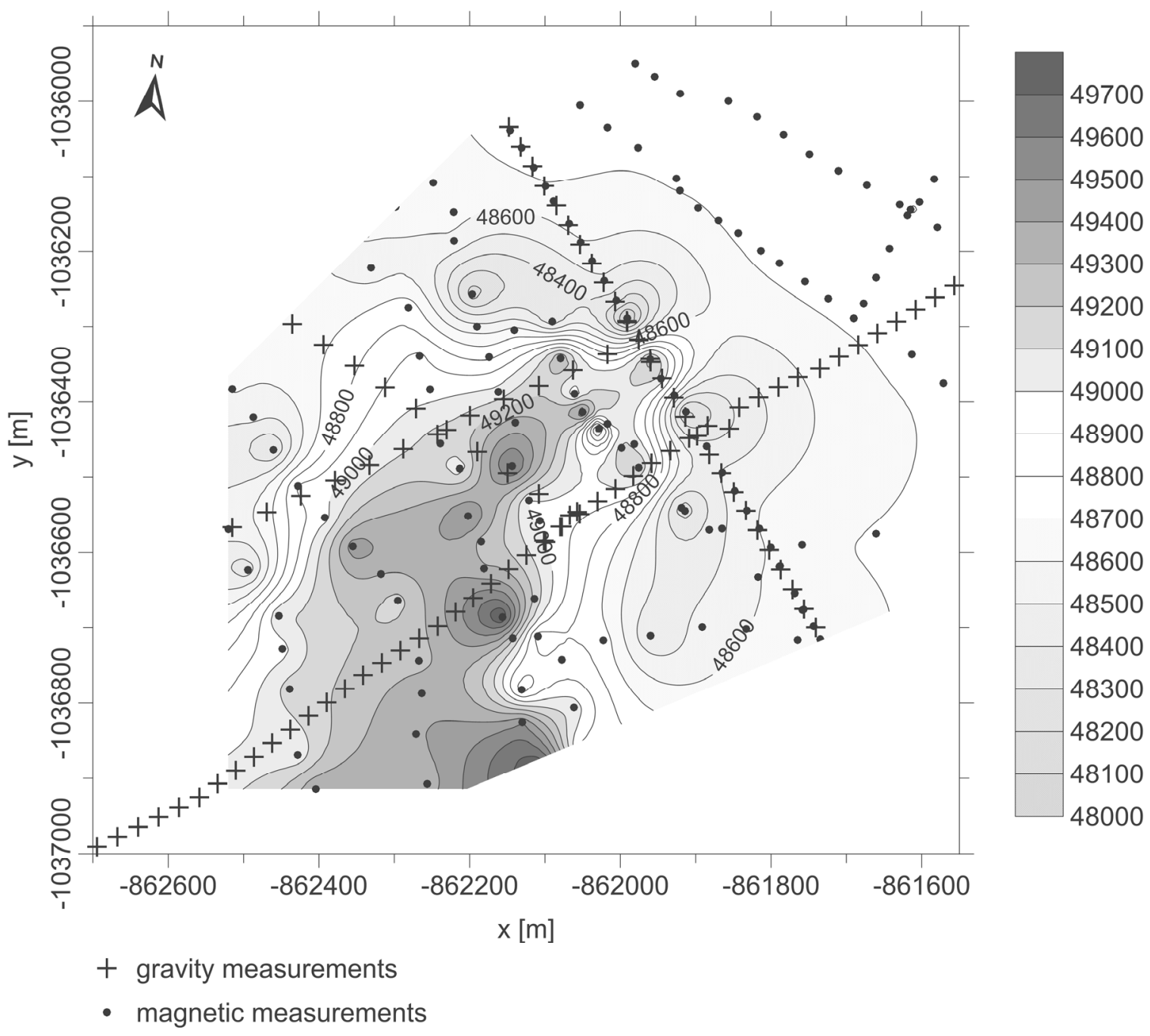

Fig. 6 Total magnetic field. The high values of the magnetic field in the centre of the area show the presence of basaltic lava intrusions.

original maar explosion but close enough to penetrate also the uppermost part of the maar-diatreme volcano. The most curious is the third one with no clear connection to a feeding system. This horizontal body could be interpreted as a lava flow. Similar lava flow filling partly the maar crater has been geophysically identified for example in La Crosa de Sant Dalmai maar (Catalonia, Spain - Bolós et al., 2012). The potential source vent of the lava flow flowing into the maar crater is located nearby - it is the Podhorní vrch scoria cone (Fig. 1). We suggest, that the Rájov maar belongs to the Podhorní vrch volcanic system and that this maar represents the first phreato-magmatic explosive event of the Podhorní vrch volcanic system. Later explosive events of the system were of the Strombolian style with a scoria cone and lava flows.

The changes in a volcanic activity are dominantly controlled by changes in degassing patterns, magma ascent rates and amount and inflow of external water (Houghton et al., 1999; Blaikie et al., 2012). Moreover, Houghton (1999) considers the magma flux to be the main influence here. He connects phreatomagmatic activity with a low magma flux during the initial stages of volcanism, where the vents are not open, or with a time of rapid readjustement and maar collapse. Later on, when the vents are open and magma flux higher, the volcanism changes into the Strombolian or Hawaiian style. A similar scenario could take place also here. A schematic diagram of this evolution is shown in Figure 8 .

The coherent mafic intrusions more than balance the mass deficit caused by the diatreme breccia. The gravity maximum resulting from the basic intrusions overrides gravity low of the diatreme and explains the unexpectedly low gravity contrast between the diatreme and surroundings mentioned in the Section 3.

The magnetic high measured in the centre of the area (Fig. 6) coincides well with that one measured by Šalanský (2009). The amplitude of it exceeds 800 nT in both cases. Salanský also interprets it in a similar way - as a body of Tertiary mafic lava (Šamanský, 2009). 


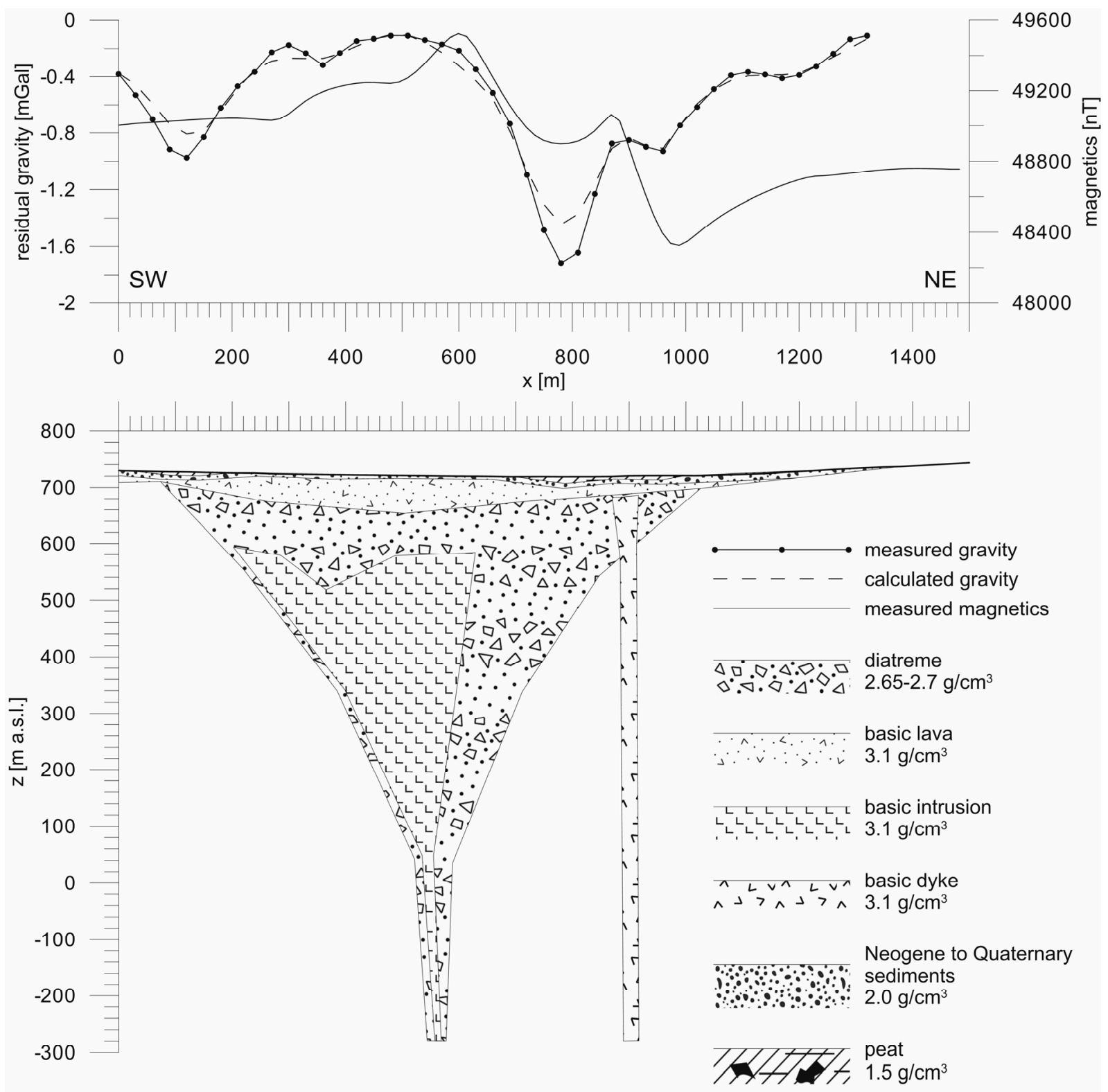

Fig. 7 Possible model of the Rájov diatreme. The model is constructed for gravity profile 1 and constrained by geological assumptions.

\section{CONCLUSIONS}

Considering results of this research, the volcanic history of the Rajov maar and the Podhorní vrch volcanic system seems to be more complex and linked together than was expected. The interpreted model shows a large maar-diatreme volcano with a crater approximately one kilometre wide and at least one kilometre deep. Several mafic intrusions were modelled within the diatreme. They were most likely emplaced in more than one eruption the topmost one being possibly a lava flow from the nearby Podhorní vrch volcanic system.

The first phreatomagmatic explosion (the Rájov maar) consumed all water available for phreatomagmatic eruptions and subsequent activity took place in Strombolian style building up a scoria cone of the Podhorní vrch volcano and emitting a lava flow, which filled partly the maar crater (Fig. 8).

\section{ACKNOWLEDGEMENTS}

This research was supported by the Grant No. IAA300120905 of the Grant Agency of the Academy of Sciences of the Czech Republic. It has been carried out within the framework of Research Plan (A VOZ30460519) of the Institute of Rocks Structure and Mechanics and Strategic Research Plan for 2012-2015 of the Czech Geological Survey (project 321140).

\section{REFERENCES}

Blaikie, T.N., Ailleres, L., Cas, R.A.F. and Betts, P.G.: 2012, Three-dimensional potential field modelling of a 


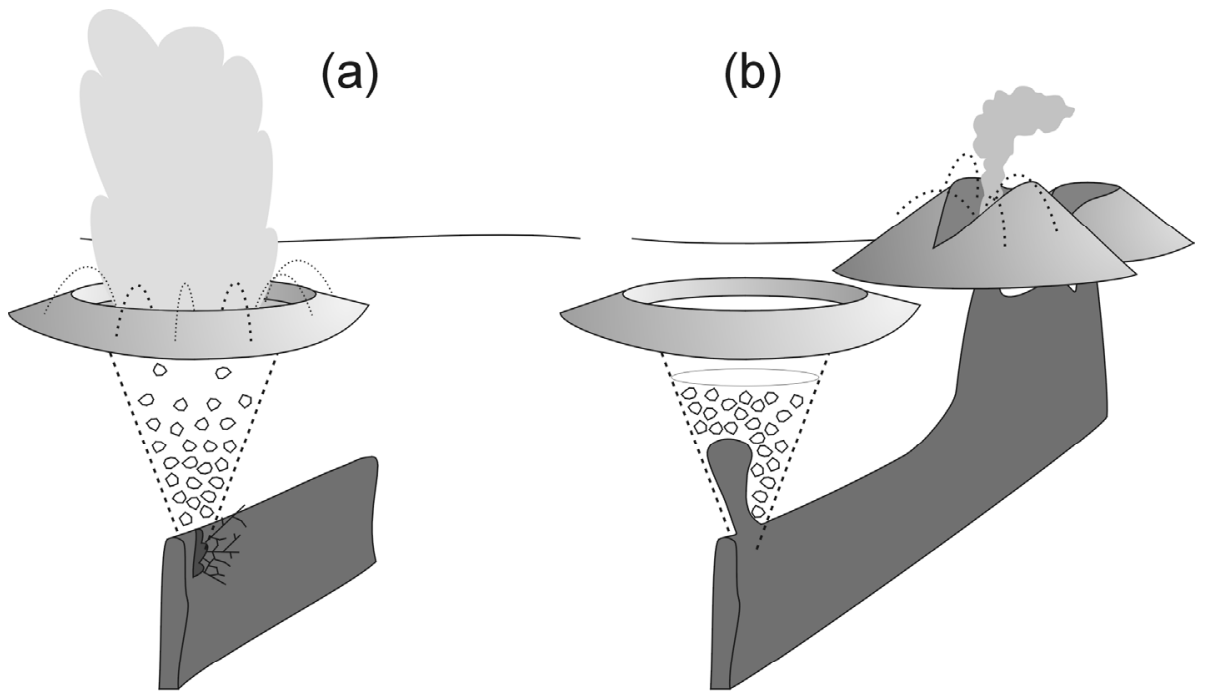

(c)

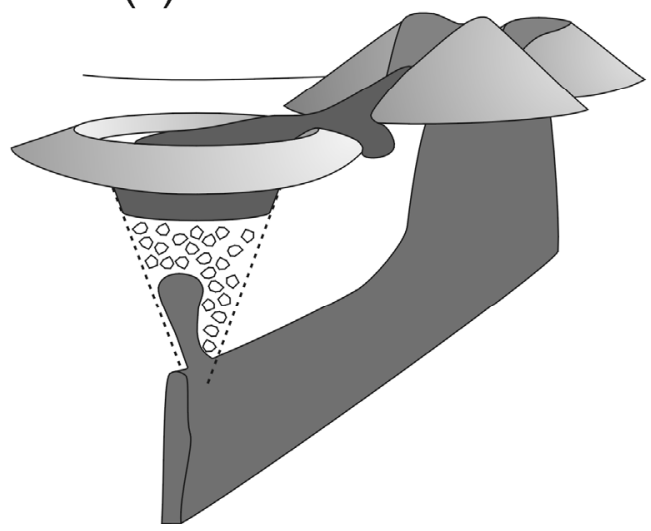

Fig. 8 Schematic reconstruction of the evolution of the Rájov - Podhorni vrch volcanic system. (a) The first phase, when the magma reached water saturated sediments and a volcanism started with a phreatomagmatic eruption. (b) Second phase, when the available water has been already used, eruption type changed to the Strombolian and the nearby scoria cone Podhorní vrch Hill is formed. Part of the basaltic lava also intruded into the already formed Rájov diatreme. (c) The last phase of the eruption, when a lava flow from the Podhorní vrch Hill filled the upper part of the Rájov diatreme.

multi-vent maar-diatreme - The Lake Coragulac maar, Newer Volcanics Province, south - eastern Australia. Journal of Volcanology and Geothermal Research, 235-236, 70-83.

DOI: $10.1016 /$ j.jvolgeores.2012.05.002

Bolós, X., Barde-Cabusson, S., Pedrazzi, D., Martí, J., Casas, A., Himi, M. and Lovera, R.: 2012, Investigation of the inner structure of La Crosa de Sant Dalmai maar (Catalan Volcanic Zone, Spain). Journal of Volcanology and Geothermal Research, 247-248, 37-48.

DOI: 10.1016/j.jvolgeores.2012.08.003

Brunner, I., Friedel, S., Jacobs, F. and Danckwardt, E.: 1999, Investigation of a Tertiary maar structure using three-dimensional resistivity imaging. Geophysical Journal International, 136 (3), 771-780.

DOI: $10.1046 / j .1365-246 x .1999 .00770 . x$
Büchner, J. and Tietz, O.: 2012, Reconstruction of the Landeskrone Scoria Cone in the Lusatian Volcanic Field, Eastern Germany - Insights on a large sized monogenetic volcano, long-lasting degradation of volcanic edifices and implications for the landscape evolution. Geomorphology, 151-152, 175-187. DOI: 10.1016/j.geomorph.2012.01.027

Cajz, V.: 1992, Volcanic history of Podhorni vrch Hill, western Bohemia. Časopis pro mineralogii a geologii, 37, 63-64.

Cassidy, J., France, S.J. and Locke, C.A.: 2007, Gravity and magnetic investigation of maar volcanoes, Auckland volcanic field, New Zealand. Journal of Volcanology and Geothermal Research, 159, 153-163. DOI:10.1016/j.jvolgeores.2006.06.007

Cooper, G.R.J.: 1997, Forward modeling of magnetic data. Computers \& Geosciences, 23 (10), 1125-1129. DOI: 10.1016/S0098-3004(97)00099-X 
Cooper G.R.J.: 2012, Grav2dc - gravity modelling and inversion, Version 2.10. Johannesburg, University of the Witwatersrand.

http://www.wits.ac.za/academic/science/geosciences/rese arch/geophysics/gordoncooper/6511/software.html, visited April 4th 2012.

Emilia, D.A., Last, B.J., Wood, C.A. and Dakin, F.M.: 1977, Geophysics and geology of an explosion crater in the Ethiopian rift valley. Bulletin of Volcanology, 40, 133-140. DOI: 10.1007/BF02596995

Gebhardt, A.C., De Batist, M., Niessen, F., Anselmetti, F.S., Ariztegui, D., Haberzettl, T., Kopsch, C., Ohlendorf, C. and Zolitschka, B.: 2011, Deciphering lake and maar geometries from seismic refraction and reflection surveys in Laguna Potrok Aike (southern Patagonia, Argentina). Journal of Volcanology and Geothermal Research, 201 (1-4), 357-363. DOI:10.1016/j.jvolgeores.2010.12.019

Head, J.W. and Wilson L.: 1989, Basaltic pyroclastic eruptions: influence of gas-release patterns and volume fluxes on fountain structure, and the formation of cinder cones, spatter cones, rootless flows, lava ponds, and lava flows. Journal of Volcanology and Geothermal Research 37, 261-271. DOI: 10.1016/0377-0273(89)90083-8

Houghton, B.F., Wilson, C.J.N. and Smith, I.E.M.: 1999, Shallow-seated controls on styles of explosive basaltic volcanism: a case study from New Zealand. Journal of volcanology and geothermal research, 91, 97-120. DOI: $10.1016 / \mathrm{S} 0377-0273(99) 00058-\mathrm{X}$

Jacoby, W. and Smilde, P.L.: 2010, Gravity Interpretation, Springer-Verlag, Berlin, Heidelberg.

Ibrmajer, J. and Suk, M. (Eds.): 1989, Geophysical pattern of Czechoslovakia (in Czech with English summary). Ústř Úst Geol, Academia, Prague, 354 pp.

Kachlík, V.: 1994, The Kladská Unit - petrological and structural evidence for Variscan thrusting of the Mariánské Lázně Complex over Saxothuringian terrane (West Bohemia). KTB Report, 94-3, 19-31.

Klomínský, J., Jarchovský, T. and Rajpoot G.S.: 2010, Atlas of plutonic rocks and orthogneisses in the Bohemian Massif - 1. Bohemicum. Czech Geological Survey, Praha, 100 pp.,

Loera, H.L., Aranda-Gómez, J.J., Arzate, J.A. and MolinaGarza, R.S.: 2008, Geophysical survey of the Joya Honda maar (México) and surroundings: volcanic implications. Journal of Volcanology and Geothermal Research, 170, 135-152. DOI:10.1016/j.jvolgeores.2007.08.021

Lorenz, V. and Kurszlaukis, S.: 2007, Root zone processes in the phreatomagmatic pipe emplacement model and conse-quences for the evolution of maar-diatreme volcanoes.Journal of Volcanology and Geothermal Research, 159, 4-32. DOI:10.1016/j.jvolgeores.2006.06.019

Lorenz, V., Suhr, P. and Goth, K.: 2003, Maar-DiatremVulkanismus - Ursachen und Folgen. Die Guttauer Vulkangruppe in Ostsachsen als Beispiel für die komplexen Zusammenhänge. Zeitschrift für Geologische Wissenschaften, 31, 267-312

Mrlina, J., Kämpf, H., Kroner, C., Mingram, J., Stebich, M., Brauer, A., Geissler, W.H., Kallmeyer, J., Matthes, H. and Seidl, M.: 2009, Discovery of the first Quaternary maar in the Bohemian Massif, Central Europe, based on combined geophysical and geological surveys. Journal of Volcanology and Geothermal Research, 182, 97-112. DOI:10.1016/j.jvolgeores.2009.01.027
Rapprich, V., Cajz, V., Košták, M., Pécskay, Z., Ř́dkošil, T., Raška, P. and Radoň, M.: 2007, Reconstruction of eroded monogenic Strombolian cones of Miocene age: A case study on character of volcanic activity of the Jičín Volcanic Field (NE Bohemia) and subsequent erosion rates estimation. Journal of Geosciences 52, 169-180. DOI: 10.3190/jgeosci.011

Šalanský, K.: 2009, Geophysical indication of unknown neovolcanic centre near Mariánské Lázně. Geoscience Research Reports for 2008, Czech Geological Survey, Prague, 283-286, (in Czech).. http://www.geology.cz/zpravy/obsah/2008/2008-78.pdf

Skácelová, Z., Rapprich, V. and Mlčoch, B.: 2009, Effect of small potassium-rich dykes on regional gammaspectrometry image of a potassium-poor volcanic complex: A case from the Doupovské hory Volcanic Complex, NW Czech Republic. Journal of Volcanology and Geothermal Research, 187, 26-32. DOI:10.1016/j.jvolgeores.2009.07.018

Skácelová, Z., Rapprich, V., Valenta, J., Hartvich, F., Šrámek, J., Radoň, M., Gaždová, R., Nováková, L., Kolínský, P. and Pécskay, Z.: 2010, Geophysical research on structure of partly eroded maar volcanoes: Miocene Hnojnice and Oligocene Rychnov volcanoes (northern Czech Republic). Journal of Geosciences, 55, 333-345. DOI: 10.3190/jgeosci.072

Štědrá, V., Kachlík, V. and Kryza R.: 2002, Coronitic metagabbros of the Mariánské Lázně Complex and Teplá Crystalline Unit: inferences for the tectonometamorphic evolution of the western margin of the Teplá-Barrandian Unit, Bohemian Massif. Geol. Soc. Spec. Publ., London, 201, 217-236.

Tietz, O., Gärtner, A. and Büchner, J.: 2011, The monogenetic Sonnenberg scoria cone - implications for volcanic development and landscape evolution in the Zittauer Gebirge Mountains since the Paleogene. Zeitschrift für Geologische Wissenschaften, 39, 311334.

Tonika, J. (ed.): 1999, Geological map of the Czech Republic 1:50 000, sheet 11-41 Mariánské Lázně. Czech Geological Survey, Praha.

Ulrych, J., Lloyd, F.E. and Balogh, K.: 2003, Age relations and geochemical constraints of Cenozoic alkaline volcanic series in W Bohemia: a review. Geolines, 15, $168-180$.

Ulrych, J., Dostal, J., Adamović, J., Jelínek, E., Špaček, P., Hegner, E. and Balogh, K.: 2011, Recurrent Cenozoic volcanic activity in the Bohemian Massif (Czech Republic). Lithos 123, 133-144.

DOI: 10.1016/j.lithos.2010.12.008

Valenta, J., Brož, M., Málek, J., Mlčoch, B., Rapprich, V., Skácelová, Z. and the Doupov Working Group: 2011, Seismic model and geological interpretation of the basement beneath the Doupovské hory Volcanic Complex, Acta Geophysica, 59, 597-617. DOI: $0.2478 / \mathrm{s} 11600-011-0009-1$

Žáček, V. and Cháb, J.: 1993, Metamorphism in the Teplá Upland, Bohemian Massif, Czech Republic (Preliminary Report). Věstník Českého geologického ústavu, 68, 33-37. 